\title{
Nigeria's construction industry: barriers to effective communication
}

DOI:

10.1108/ECAM-01-2016-0003

\section{Document Version}

Accepted author manuscript

Link to publication record in Manchester Research Explorer

\section{Citation for published version (APA):}

Ejohwomu, O., Oshodi, O., \& lam, K. C. (2017). Nigeria's construction industry: barriers to effective communication. Engineering Construction and Architectural Management, 24(4). https://doi.org/10.1108/ECAM-012016-0003

\section{Published in:}

Engineering Construction and Architectural Management

\section{Citing this paper}

Please note that where the full-text provided on Manchester Research Explorer is the Author Accepted Manuscript or Proof version this may differ from the final Published version. If citing, it is advised that you check and use the publisher's definitive version.

\section{General rights}

Copyright and moral rights for the publications made accessible in the Research Explorer are retained by the authors and/or other copyright owners and it is a condition of accessing publications that users recognise and abide by the legal requirements associated with these rights.

\section{Takedown policy}

If you believe that this document breaches copyright please refer to the University of Manchester's Takedown Procedures [http://man.ac.uk/04Y6Bo] or contact uml.scholarlycommunications@manchester.ac.uk providing relevant details, so we can investigate your claim.

\section{OPEN ACCESS}




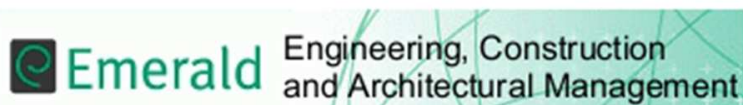

\section{Nigeria's construction industry: barriers to effective communication}

\begin{tabular}{|r|l|}
\hline Journal: & Engineering, Construction and Architectural Management \\
\hline Manuscript ID & ECAM-01-2016-0003.R2 \\
\hline Manuscript Type: & Original Article \\
\hline Keywords: & $\begin{array}{l}\text { Attribution theory, barriers, communication, Construction Industry, Nigeria, } \\
\text { Organizations }\end{array}$ \\
\hline Abstract: & \\
\hline \multicolumn{2}{|r}{} \\
\hline
\end{tabular}

SCHOLARONE ${ }^{\text {w }}$

Manuscripts 


\title{
Nigeria's construction industry: Barriers to effective communication
}

\begin{abstract}
Purpose - Communication plays an important role in the quality of the relationship, trust and collaboration among construction project teams. Literature suggests that effective communication is vital for achieving improved project performance. The aim here is to identify and assess the barriers to effective communication in the Nigerian construction industry, using attribution theory paradigm.
\end{abstract}

Design/methodology/approach - Questionnaires detailing 15 barriers to effective communication were administered to consultants and contractors engaged in the Nigerian construction sector. One hundred valid responses were analysed using mean score, factor analysis and factor score.

Findings - Unclear project objectives, ineffective reporting systems and poor leadership were ranked as the most significant barriers to effective communication. Factor analysis uncovered that the principal reasons responsible for ineffective communication include: managerial and technical barriers and credibility and background barriers.

Practical implications - The results provide information on barriers which needs to be addressed in order to improve communication in construction projects in Nigeria. There is a need to conduct post-completion reviews of construction projects so that project team members can learn and share knowledge on past experiences. Although the present study was conducted in the Nigerian context, it is envisaged that the research outcome will be widely applicable to other developing countries. 
Originality/value - The study provides insights on the perceived barriers to effective communication in Nigerian construction projects. The paper presents the direction for further research aimed at improving communication in construction projects in Nigeria.

Keywords Attribution theory, barriers, communication, construction industry, Nigeria, Organisation

Paper type Research paper

\section{INTRODUCTION}

Poor performance of construction projects remain a major problem in both developing and developed countries (Flyvbjerg et al., 2003). Almost every publication in the field of construction management reiterates this concern. Although Toor and Ogunlana (2010) have suggested the need to use other metrics (such as safety, stakeholder satisfaction, etc.) to evaluate performance of construction projects; cost, time and quality largely remains the most popular performance indicators. Despite the existence of several studies addressing poor performance of construction projects (AlSehaimi et al., 2013; Ramanathan et al., 2012), it is evident that this remains a re-occurring problem. Empirical evidence from a previous study suggests that ineffective communication among stakeholders is a significant factor responsible for poor performance of construction projects (Atkinson, 2002; $\mathrm{Ng}$ et al., 2004). In a similar vein, Meng (2012) found that improved communication amongst stakeholders is vital to meeting project performance objectives. Hence, an understanding of communication practice within the construction industry is an important element in the process of improving performance of construction projects. The present research effort focuses on gaining insights into the factors responsible for ineffective communication in the Nigerian construction industry.. 
In recent years, researchers in the field of construction management have shown an increased interest in communication-related studies. Trade liberalization and the need to exploit markets in foreign countries have created new communication problems in the construction industry which arise due to multi-cultural work environment (Loosemore and Lee, 2002; Ochieng and Price, 2010). Other studies have investigated the use of Information and Communication Technology (ICT) in the construction industry (Duyshart et al., 2003; Ng et al., 2001; Peansupap and Walker, 2005); communication between design team and construction manager (Shohet and Frydman, 2003); and communication practice in construction projects (Gorse and Emmitt, 2003; Tai et al., 2009). There is limited evidence of studies addressing communication problems in the construction industry in Africa (Ejohwomu and Oshodi, 2014; Laryea and Leiringer, 2012); except for Kwofie et al. (2015) which addresses ineffective communication in mass housing projects in Ghana. Also, lack of studies focused on communication in project management literature has been linked to project failures (Dainty et al., 2006; Akintoye and Shehu, 2010). Using the lens of attribution theory, the present study examines what construction professionals attribute to as the barriers to effective communication in projects. Hence, the following objectives are addressed: (1) to identify the barriers to effective communication in construction projects; and (2) to assess the barriers to effective communication in construction projects.

The remainder of this report is structured into four sections. First, a review of literature, attribution theory and theoretical framework is presented in the next section. The underlying science that guides the choice of research method and the procedures of conducting the study is explained in the research methods section. This is preceded by data analysis in section three and findings of cross-sectional survey on communication practices in section four. 


\section{REVIEW OF LITERATURE}

\section{Barriers to effective communication in the construction industry}

Effective communication between construction project stakeholders (client, contractors, suppliers, users, etc.) is central to achieving improved performance of construction projects. Generally, there is no accepted definition for 'communication' as the term can be viewed from various perspectives. Dainty et al. (2006) describes effective communication as a process whereby feedback is received for information that is transmitted. Furthermore, Dainty et al. (2006) points out that as the construction industry moves towards a largely service oriented industry (most of the production activities are outsourced); there is a need for effective communication to improve knowledge sharing, collaboration and integrate all individuals involved in the construction process. This will improve project performance and serve as a feedback process to drive improvements in the construction sector. It is worth mentioning that communication takes place not only between individuals involved in a construction project, but also among organisations. Understanding the barriers to effective communication is crucial to improving the process of communication during construction projects.

As evident from literature, effective communication is vital for trust, collaboration, and improved performance of construction projects (Bond-Barnard et al., 2013). From a normative view point, a number of studies have explored significant factors that affects the effectiveness of communication among construction project team and stakeholders. Gil (2010) utilised a case study approach to evaluate how changes in tone (language) affect communication in a construction project. Carlsson et al. (2001) sought to investigate factors affecting communication, communication patterns, reasons for communication and communication 
methods. It was found that project type, project briefing and time are major factors that reduce the effectiveness of communication in construction projects. Similarly, Pietroforte (1997) proposed a framework for analysing the contractual process and information requirement in the building process. It was revealed that differences in the perception of project team members and nature of information affects information flow. Research also showed that differences in personality and interest, lack of checking information with users and craftsmen, use of inappropriate visualization techniques, insufficient resources (time and manpower), timing of information, work experiences, client's attitude, site constraints, cultural barriers and organisational cultural barriers were factors affecting effective communication between clients and maintenance contractors (Goh et al., 2005). Table 1 provides a summary of previous studies on this research topic.

\section{'Insert Table 1 here'}

As can be seen in Table 1, a large majority of the studies were conducted in developed countries, except for two studies which focused on Kenya and United Kingdom (Ochieng and Price, 2010) and Ghana (Kwofie et al., 2015). For example, factors affecting communication in construction projects in Australia (Loosemore and Lee, 2002); Singapore (Loosemore and Lee, 2002; Goh et al., 2005); and United States of America (Thomas et al., 1998). A difference was found to exist in communication patterns utilized in heavy engineering projects executed in Kenya and UK (Ochieng and Price, 2010). This suggests that the findings of studies conducted in the developed world may not be generalizable to developing countries. This indicates a need to understand the perception of construction professionals on factors affecting the effectiveness of communication in the context of developing countries. The present study reported here addresses this gap that exists in literature. 


\section{Theoretical framework}

Every construction project is characterized by their unique nature, have pre-defined performance goals; involves multiple project stakeholders; entails different project phases (preplanning, execution and post-construction); and the execution phase is complex. As different phases of the project involve several academic disciplines (e.g. engineers, architects, etc.) of diverse culture and background; there is need for effective communication among project participants. As shown in the preceding sections of this paper, communication significantly affects the chances of meeting pre-planned project objectives, and thus must be properly managed. Therefore, attribution theory is used in this study to address questions relating to barriers to effective communication among contracting parties, this is essential for improving project outcomes.

\section{Attribution theory}

As stated in the preceding section; the origins of ineffective communication in construction projects have various root causes. Attribution theory is principally concerned with how people interpret information in order to determine the causes of an event. Reactions to similar events are influenced by causal attribution attached by individuals (Kelley and Michela, 1980; Savolainen, 2013). Although attribution theory has been utilized in several studies in the field of psychology, it has also been found useful in communication-related studies (see Lalljee, 1987; Laczniak et al., 2001; Jeong, 2009). Attribution theory was chosen for application to explain the barriers to effective communication in the present study for two reasons. First, the theory helps to achieve "cognitive control" needed to explain factors giving rise to ineffective communication. Second, two important features of ineffective communication are: they are 
unanticipated and have negative impact. There are key questions that attribution theory seeks to address by identifying the cause of an event (Weiner, 1985; Kelley and Michela, 1980). Kelley and Michela (1980) classified studies that have applied attribution theory into two groups based on focus: casual attribution (i.e. studies focused on explaining perceived cause of an event) and consequence (studies that measure impact of causes on outcome). The present study focuses on causal attribution. Thus, attribution theory plays an important role in explaining the factors that construction firms perceive as barriers to effective communication in projects.

Causal attributions have been categorised into two distinct groups: internal and external. Internal attribution refers to inferences which are made based on factors that an individual has control over (e.g. personality traits, motives, etc.); and external attribution are inferences which evolve from issues over which a person has little or no control (Plotnik and Kouyoumdjan, 2011). Results emanating from previous studies have shown that people tend to associate success with internal attribution; however, failure is linked to external attribution (Franco and Haase, 2010; Luo et al., 2005; Peterson et al., 2002). Attribution theorists term this behaviour as 'selfserving' bias. The finding of some studies (such as Brubaker, 1988) do not agree to this. This is referred to as 'self-effacing' bias. In addition, empirical evidence revealed that there are differences in the perception of actors and observers about the cause of an event (Rogoff et al., 2004; Stewart, 2005). Despite these limitations, Kelley and Michela (1980) acknowledges that attribution theory has provided 'meaningful' answers that addresses causal attribution problems.

Notably, attribution theory has been applied in construction-related studies. The theory has been applied to explain factors responsible for occurrence of human errors (Atkinson, 1998); nail gun injury (Albers et al., 2014) and effectiveness of communication in mass housing projects (Kwofie et al., 2015). It was found that supervisors attributed human errors in construction 
projects to external attribution (Atkinson, 1998). Poor formal communications is principally responsible for errors, which leads to defects in construction projects (Atkinson, 2002). Risk associated with tools, unsafe behaviours and work pressures were identified as important factors responsible for nail injuries (Albers et al., 2014). Finally, Kwofie et al. (2015) classified factors responsible for ineffective communication into three groups namely: access to information challenges, challenges in flow of information and component; and import of information challenges. Based on the foregoing, it is reasonable to suggest that attribution theory is useful in explaining the cause of an event. Identifying the causal attribution associated with the occurrence of an event is crucial to developing and implementing response strategies in the future. The present study extends the work into ineffective communication in construction projects in developing countries which has been acknowledged as an important problem. Hence, the attributions linked with ineffective communication are examined.

\section{RESEARCH METHOD}

To date, various methods have been used to investigate communication problems in the field of construction management. Dainty (2008) categorized research approaches utilized in construction management studies into four groups namely quantitative, qualitative, mixed and review. The factors that affects choice and suitability of a particular research method are largely dependent on the research situation and research problem (Yin, 1994; Wing et al., 1998). The need to compare and replicate, maintain low interference between researcher and participants, objective measurement of the phenomenon been studied, objective assessment of reliability of validity of findings, generalization of findings and testing of a hypothesis are key strengths of the 
quantitative approach (Amaratunga et al., 2002; Wing et al., 1998). A questionnaire survey approach was chosen because it is suitable for collecting data from a large group of respondents (i.e. contractors, clients and consultants). This approach has also been used in similar previous studies (see Shohet and Frydman, 2003; Thomas et al., 1998) found in literature.

A modified questionnaire used in a similar previous work (Affare, 2012) was used in the present study. The questionnaire was modified based on other barriers identified from the review of literature. Pilot surveys and feedback from this process (i.e. feedback from the respondents of the pilot survey) ensured that the barriers in the Nigerian context are properly captured. The final list of 15 barriers to effective communication in construction projects in Nigeria formed the main content of the questionnaire design (see Table 2). The respondents were asked to evaluate the degree to which each item was a barrier to effectiveness of communication using a five-point Likert scale in which ranged from ' $5=$ strongly agree to $1=$ strongly disagree'. In addition, an open-ended question was added to the questionnaire so as to identify the most preferred medium of communication in construction projects

A total of 200 questionnaires were administered to construction firms operating in Nigeria. The sample for the study was purposively drawn from over 400 organizations registered with Association for Consulting Engineering in Nigeria (ACEN), Federation of Construction Industry (FOCI), Quantity Surveyors Registration Board of Nigeria (QSRBN), Architects Registration Council of Nigeria (ARCON) and large client organisations (private and government departments in charge of procuring construction projects). Purposive sampling ensured that the respondents are employed in organisations currently handling at least one or more construction project(s). This is to adequately capture the barriers in the context of current happenings in the Nigerian construction sector. 
Out of the 200 questionnaires distributed, 100 were received and valid for further analysis. Out of the 100 respondents, 20\% were engaged in private client organisations, 34\% contracting firms, $18 \%$ consulting firms, and $28 \%$ public client organisations. In terms of respondents' years of experience, $71 \%$ had over 5 years of experience. This indicates that a good spread of different professional with varying background and long years of experience are represented in the survey.

Cronbach's alpha coefficient is a measure used to determine internal consistency. In this study, the value of Cronbach's alpha coefficient test was 0.774 . This suggests that the responses obtained based on the five-point Likert scale can are reasonably reliable.

\section{Tools for data analysis}

\section{Mean Score}

Cheung et al. (2010) used "mean score" as a tool to determine the rank of "attractive" and "negative" factors for adopting the use of PPP in projects as suggested by respondents in Hong Kong and Australia. The data collected from the current survey was analysed using the same technique. Detailed description of the process of calculating mean scores can be found in Cheung et al. (2010). Responses received based on the five-point Likert scale (described earlier) was used to calculate the mean score for each barrier. The mean score served as a metrics for ranking the barriers.

Factor analysis

Exploratory factor analysis (EFA) is a technique used to reduce the number of variables into a smaller and meaningful number of factors (Ho, 2014). Principal component 
analysis (PCA) was utilised, this is because of its wide application (Hon et al., 2013). Two tests, Kaiser-Meyer-Olkin (KMO) and Bartlett's test of sphericity, are conducted prior to factor extraction so as to confirm suitability. The value of KMO statistic in the present study is 0.668 . This is above the minimum acceptable value of 0.50 as reported in Chan (2012). In addition, Bartlett's test of sphericity should be significant $(\mathrm{p}<0.05)$, this signifies adequacy of correlation matrix (Ho, 2014). In the present study, Bartlett's test of sphericity yielded a value of 565.6871 and an associated degree of significance smaller than 0.000. Thus, the hypothesis that the correlation matrix is an identity matrix is rejected. As a rule of the thumb, the factor loadings which range between 0.3-0.4 are considered to be within the acceptable proposed threshold (Hair et al., 2010).

\section{'Insert Table 2 here'}

\section{DATA ANALYSIS}

\section{Ranking of the barriers to effective communication}

The mean values and standard deviation of the barriers to effective communication served as a basis for ranking in the order of significance. As shown in Table 3, the top 5 ranked barriers influencing effective communication in Nigerian construction projects include: (1) unclear objectives; (2) ineffective reporting system; (3) poor leadership; (4) lack of necessary skills; and (5) unclear channels of communication. However, religious issues, conflicting cultural values, and age differences were the least ranked barriers to effective communication.

\section{'Insert Table 3 here'}


Underlying Dimension of Barriers to Effective Communication - Factor analysis

In the present study, the factor loading was set at 0.4 in the Statistical Package for the Social Sciences (SPSS) software and all loading above the set value are retained. The next challenge is to determine the number of the factors to be extracted. To achieve this, three different test were considered which include Kaiser's criterion, scree test and parallel analysis. With the aid of parallel analysis which is considered as the most accurate approach (O'Connor, 2000), the number of factor to be extracted was determined. By comparing the results of the actual eigenvalue from PCA (SPSS output) with those of parallel analysis (see Table 4), the value obtained from SPSS must be greater than the criterion value in order to accept.

\section{'Insert Table 4 here'}

The two-component solutions that encapsulated the 15 variables explaining a total variance of $43.39 \%$ are listed as follows (Table 5):

- Managerial and technical barriers: this factor consisted of 9 items and $28.62 \%$ of the total variance. Some of the items were related to managerial issues (F3, F5, F6, and F8). Other variables were related to technical or expertise issues (F1, F2, F4, F7, and F9).

- Credibility and background barriers: this factor was composed of six items, explaining $14.78 \%$ of the total variance. This factor described what individuals and/or group individual value and experienced.

\section{'Insert Table 5 here'}

The factor loadings explain the correlation among the variables in a factor component. Fan and Fox (2009) affirm that this does not highlight the significance of the factor. To address this concern, the relative importance of the factors extracted (see Table 5) is determined by using 
factor scores (Fan and Fox, 2009). The formula for factor scores is expressed in Equation 1 below.

$F i=\frac{\sum_{j=1}^{n} A i j}{n}$

Where $F i=$ factor score; $A i j=$ mean score of the $j$ th attribute of factor; $i$ and $n=$ the number of attributes associated with the factor.

Using the mean score of each item that relates to each factor to compute a factor score, it was revealed that 'managerial and technical' factor ranked highest with a factor score of 3.77 and the lowest ranked is 'credibility and background' factor (factor score $=3.20$ ).

\section{DISCUSSION OF FINDINGS}

\section{Discussion of mean score results}

The results of the current study are in line with those of previous studies (Daim et al., 2012; Golen et al., 1997; Tai et al., 2009). The finding of Daim et al. (2012) showed that trust, interpersonal relations, cultural differences, leadership and technology are major causes of communication breakdown among global virtual teams (Daim et al., 2012). Also, the causes of communication problems in large scale construction projects in China are: lack of good communication mechanism, weak organizational structures of construction teams, lack of uniform standards for construction information, and lack of support for advanced communication technologies (Tai et al., 2009). Similarly, Similarly, Golen et al. (1997) found that distortion/omission of information, lack of credibility, lack of trust, hostile attitude and inadequate common accounting knowledge are barriers to communication between client and 
auditor. It is imperative to note that trust and personal attributes were the most significant factors identified in Golen et al. (1997), this differs from the results of the present study reported here. This inconsistency may be due to differences in characteristics of respondents surveyed. It can therefore be suggested that clearly defined objectives; adopting and implementing an effective mechanism for reporting progress in projects; providing strong leadership; training and retraining construction professionals on effective communication skills; and development of clearly defined communication channels among project stakeholders are crucial actions needed to improve the effectiveness of communication in construction projects.

\section{Discussion of factor analysis results}

Understanding the barriers to effective communication on construction projects is important to improving project performance. This study reports those communication barriers perceived by construction professionals as detrimental to the relationship among construction project teams. These barriers as identified from an initial literature review (used in developing survey instrument) and ranked based on the perceptions of the respondents were categorized into two main groups. In essence, these two factors are believed to be the factors inhibiting communication in construction organisations and focusing on these major factors will lead to an improvement in the effectiveness of communication. Details of the factors are discussed in the next subsections.

\section{Factor 1: Managerial and technical factor}

The "managerial and technical" factor encapsulates nine barriers: (1) political/community interference, (2) poor listeners, (3) poor leadership, (4) unclear objectives, (5) conflicting cultural values, (6) unclear channels of communication, (7) ineffective reporting system, (8) limited 
resources and (9) information filtering. The factor accounts for $28.62 \%$ of the total variance explained among all the barriers (Table 5).

Many studies have demonstrated that issues relating to management and technical factors are critical to improving the effectiveness of communication in construction projects. Bowen and Edwards' (1996) exploratory study on effectiveness of cost plan communication at the design stage of building project revealed that improvements can be achieved by ensuring that project document (engagement letters and service agreements) are worded in explicit terms. In a similar vein, findings from Goh et al. (2005) identified that 'lack of checking information with users and craftsmen 'and 'use of inappropriate visualization' are critical barriers to effective communication in building maintenance projects. Dawood and Sikka (2007) conducted experiments using 4D models and 2D CAD (computer-aided design) drawings. Communication, coordination and retention of information were more effective in the group that used 4D models when compared with the 2D group. Also, it was found that client high expectations, government regulations and inadequate training for small construction firms are critical challenges to communication of health and safety information at design stage of construction projects. The results emanating from these studies highlight the importance of managerial and technical issues.

In dealing with managerial and technical barriers, efforts should be directed towards adequate briefing of all stakeholders (contractors, client, consultants and others) of the intended objectives of a construction project at the inception. In addition, there is a need to adopt the use of new visualization technologies, such as building information modelling (BIM), in the process of managing the design and execution phases of construction projects. This will ensure that all project stakeholders get a better visual representation of the information been transmitted and respond in a way that meets the need of the information sender. Most of the items under this 
barrier category can be addressed by the client and its representative (i.e. the consultants) by providing leadership and adequate feedback mechanism towards improving the effectiveness of communication among different individuals involved in construction projects.

\section{Factor 2: Credibility and background factor}

This factor consist of six barriers related to 'credibility and background' in Nigerian construction projects: (1) conflicting business/industry ethics, (2) lack of necessary skills, (3) lack of trust, (4) religious issues, (5) language difficulties, and (6) age differences. This factor accounts for $14.78 \%$ of variance explained among all barriers (Table 5).

According to Dada and Jagboro (2007), the traditional method is the most used in procuring construction projects in Nigeria. In the traditional procurement process, project teams are formed on an ad-hoc basis. Gorse and Emmitt (2007) found that 'work environment' and 'working relationship' among project teams has an influence on the effectiveness of communication. English (2002) conducted cross-cultural training with workers in the construction industry of South Africa, and found that the training resulted in improvements in communication and cooperation. Empirical evidence has shown the importance of skills in improving the effectiveness of communication (Goodwin, 1993; Bowles et al., 2001; Stein et al., 2005).

In the Nigerian construction sector, a large majority of construction professionals and client still prefer the traditional procurement system. The use of partnering and other forms of relational contracting methods is still unpopular, despite reported benefits in previous studies. 'Improved relationship amongst project participants', ‘improved communication amongst project participants' and 'more responsive to the short-term emergency, changing project or business 
needs' are regarded as the most important benefits of partnering in construction projects (Chan et al., 2003). Based on the foregoing, it is evident that there is a need for training and retraining Nigerian construction professionals in the areas related to ethics, managing different cultures in project teams and application of relational contracting.

\section{Attribution dimensions}

To determine if the 15 barrier items could be reduced into meaningful factors, factor analysis (Table 5) was conducted on the responses obtained from the survey. The first cluster consists of nine barrier items relating to management and technical issues. The second component consists of six items and was labelled as credibility and background factor. The credibility and background factor was considered as internal attribution (i.e. barriers that are within the control of construction professionals). However, management and technical factor were considered as external attribution. This is because construction professionals do not necessarily have control over these barriers.

Based on the factor score (which was computed using mean score of the barrier items in each factor group), the 'managerial and technical barriers' factor were rated higher than the 'credibility and background' factor. This shows that the external attribution was rated relatively higher than internal attribution as factors which act as barriers to effective communication in construction projects. Hence, it is reasonable to suggest that the responses to the survey exhibit self-serving bias. There are no previous studies focused on Nigeria to compare the findings of the present research with. However, the findings are consistent with those obtained by Gyekye and Salminen (2006), it was found that witness (workers) of industrial accidents linked event causality more with external attributions. A possible explanation for this might be that 
construction professionals in Nigeria exhibit defensive behaviour so as not to be held culpable for failure (i.e. unsuccessful outcome of an event). This line of argument is supported by assertions found in Dlakwa and Culpin (1990) study on causes of overrun in government-funded projects in Nigeria. The need for government to take proactive action aimed at improving project outcomes was recommended (Dlakwa and Culpin, 1990). It can therefore be assumed that construction professionals are more likely to assign unsuccessful outcomes to external attribution.

\section{SIGNIFICANCE, LIMITATIONS AND AREAS FOR FURTHER RESEARCH}

Previous studies have shown that identifying significant factors causing a problem is critical to improving professional practice in the industry (see Hon et al., 2013; Jarkas and Bitar, 2012). Effective communication is beneficial to various stakeholders involved in construction projects. The present study focuses on examining the barriers to effective communication. Fifteen barriers to effective communication were identified and the importance of each examined via a cross-sectional survey. The research findings provide stakeholders (i.e. clients, consultants and contractors) with valuable insights needed to overcome these barriers and improve communication in Nigerian construction projects.

Despite the importance of the findings of the present study, it is important to note that the generalizability of the result is limited. Questionnaire surveys always entail the risk of respondent's bias, sampling approach and imprecise definition. However, it is assumed that purposively selecting respondent will minimize these limitations. Also, the numbers of response from the consultant group is relatively small. It may be viewed that there is an overreliance on 
the perception of client organisations. The effects of these limitations can be addressed by taking a larger sample size in future studies. In future investigations, it might be possible to use a combination of quantitative and qualitative research methods. This would provide deeper insights into the impact of characteristics of respondents (such as years of experience; position with organisation, etc.) on factors considered as barriers to effective communication in construction projects.

\section{CONCLUSIONS AND RECOMMENDATIONS}

In order to identify and assess the barriers to effective communication among project teams within the construction industry, a cross-section survey was conducted. Previous studies found in construction management literature affirm that effective communication among project team will result in improved project outcomes. In addition, very little is known about barriers to communication in developing counties. The present study addresses the gap in knowledge by examining barriers to effective communication in the Nigerian construction industry using attribution theory paradigm.

The study has identified 'unclear objectives', 'ineffective reporting system' and 'poor leadership' are the main barriers to effective communication in Nigerian construction projects. Using factor analysis, the underlying relationships among the 15 barriers were further explored. The barriers are categorised into two groups: managerial and technical (external attribution) factor and credibility and background (internal attribution) factor. Interestingly, 'self-serving' bias was observed in the responses collected from the survey. The findings of this study provide some practical implications, especially for stakeholders in the Nigerian construction industry (contractors, consultants, client, academics, etc.). Self-serving bias implies that construction 
professionals will associate ineffective communication with external attribution (i.e. causes of ineffective communication are beyond their control). This suggest that Nigerian construction professional will fail to learn from experience partly due to self-serving bias. Thus, they may continue using the same process and techniques, regardless of whether or not they are effective.

Overall, the findings of the study suggest there is a need for post-completion review of construction projects. As suggested in Standing et al. (2006), when formal evaluation of project teams are not done, there is a high likelihood that team members will attribute performance of project wrongly. This can be achieved through enlightenment programmes targeted at informing stakeholders of the importance and accruable benefits of conducting a formal review of completed projects. In addition, there is a need to encourage the use of relational contracting as suggested earlier in the body of this paper.

Although the geographical scope of the present study is limited to Nigeria, the findings can be extrapolated to the construction industry in any other developing country. Barriers to communication effectiveness in Nigerian construction projects tend to be context-specific and unique. However, certain generic practices in the Nigerian construction sector are likely to be occur in other developing countries as well. Job characteristics, work environments and societal problems experienced are typical examples of common features that might exist in the construction industry of developing countries (such as Ghana, Egypt and Zambia). A critical look at previous studies on Nigeria, Egypt and Zambia reveals that finance-related factors are significant causes of poor performance of construction projects (Abd El-Razek et al., 2008; Aibinu and Odeyinka, 2006; Kaliba et al., 2009). Also, the low use of information and communication technology is observed in the Nigerian and Ghanaian construction sector (see Oyediran and Akintola, 2011; Fugar et al., 2013). The findings that emerge from these previous 
studies show that the challenges faced by the construction sector of developing countries are largely similar. Therefore, it is reasonable to suggest that the barriers to effective communication derived from the Nigeria construction industry would be relevant in other developing countries.

\section{REFERENCES}

Abd El-Razek, M., Bassioni, H. and Mobarak, A. (2008), "Causes of Delay in Building Construction Projects in Egypt." Journal of Construction Engineering and Management, 10.1061/(ASCE)0733-9364(2008)134:11(831), pp. 831-841.

Affare, M. A. W. (2012), An assessment of project communication management on construction projects in Ghana, Unpublished Master's thesis. Kwame Nkrumah University of Science and Technology.

Aibinu, A. and Odeyinka, H. (2006), "Construction Delays and Their Causative Factors in Nigeria." Journal of Construction Engineering and Management, 10.1061/(ASCE)07339364(2006)132:7(667), pp. 667-677.

Albers, J. T., Hudock, S. D., and Lowe, B. D. (2014), 'Residential building stakeholders' attitudes and beliefs regarding nail gun injury risks and prevention." New solutions: a journal of environmental and occupational health policy, Vol. 23 No. 4, pp. 577-605.

AlSehaimi, A., Koskela, L., and Tzortzopoulos, P. (2013). "Need for Alternative Research Approaches in Construction Management: Case of Delay Studies.” Journal of Management in Engineering, 10.1061/(ASCE)ME.1943-5479.0000148, pp. 407-413.

Amaratunga, D., Baldry, D., Sarshar, M. and Newton, R. (2002), "Quantitative and qualitative research in the built environment: application of "mixed" research approach." Work study, Vol. 51 No. 1, 17-31. 
Atkinson, A. (1998), "Human error in the management of building projects." Construction Management and Economics, Vol. 16 No. 3, pp. 339-349.

Atkinson, A. R. (2002), "The pathology of building defects; a human error approach." Engineering Construction and Architectural Management, Vol. 9 No. 1, pp. 53-61.

Bond-Barnard, T.J., Steyn, H. and Fabris-Rotelli, I. (2013), "The impact of a call centre on communication in a programme and its projects." International Journal of Project Management, Vol. 31 No. 7, pp. 1006-1016.

Bowen, P. A. and Edwards, P. J. (1996), "Interpersonal communication in cost planning during the building design phase." Construction Management and Economics, Vol. 14 No. 5, pp. 395-404.

Bowles, N., Mackintosh, C. and Torn, A. (2001), 'Nurses' communication skills: an evaluation of the impact of solution-focused communication training." Journal of Advanced Nursing, Vol. 36 No. 3, pp. 347-354.

Brubaker, B. H. (1988), “An attributional analysis of weight outcomes.” Nursing research, Vol. 37 No. 5, 282-289.

Canales, A., Arbelaez, M., Vasquez, E., Aveiga, F., Strong, K., Walters, R., Jaselskis, E., and Jahren, C. (2009), "Exploring Training Needs and Development of Construction Language Courses for American Supervisors and Hispanic Craft Workers." Journal of Construction Engineering and Management, 10.1061/(ASCE)0733-9364(2009)135:5(387), pp. 387-396.

Carlsson, B., Josephson, P.E. and Larson, B. (2001), "Communication in building projects: empirical results and future needs." In: CIB World Building Congress: Performance in Product and Practice, 2-6 April. Wellington, New Zealand. 
Chan, A.P.C., Chan, D. W., and Ho, K. S. (2003), "An empirical study of the benefits of construction partnering in Hong Kong." Construction Management and Economics, Vol. 21 No. 5, pp. 523-533.

Cheung, E., Chan, A. P.C., and Kajewski, S. (2010), "Suitability of procuring large public works by PPP in Hong Kong.” Engineering, Construction and Architectural Management, Vol. 17 No. 3, pp. 292-308.

Chan, C.T.W. (2012), “The principal factors affecting construction project overhead expenses: an exploratory factor analysis approach.” Construction Management and Economics, Vol. 30 No. 10, pp. 903-914.

Dada, J. O. and Jagboro, G. O. (2007). "An evaluation of the impact of risk on project cost overrun in the Nigerian construction industry." Journal of Financial Management of Property and Construction, Vol. 12 No. 1, pp. 37-44.

Daim, T.U., Ha, A., Reutiman, S., Hughes, B., Pathak, U., Bynum, W. and Bhatla, A. (2012), "Exploring the communication breakdown in global virtual teams." International Journal of Project Management, Vol. 30 No. 2, pp. 199-212.

Dainty, A. (2008), Methodological pluralism in construction management research. In A. Knight and L. Ruddock, eds. Advanced research methods in the built environment. John Wiley and Sons, United Kingdom, pp. 1-13.

Dainty, A., Moore, D. and Murray, M. (2006), Communication in Construction: Theory and Practice, Taylor and Francis, London.

Dawood, N. and Sikka, S. (2007), "Measuring the effectiveness of 4D planning as a valuable communication tool", in Boyd, D. (Ed.) proceedings of the 23rd Annual ARCOM 
Conference in Belfast, UK, 2007, Association of Researchers in Construction Management, pp. 451-460.

Dlakwa, M. M. and Culpin, M. F. (1990), "Reasons for overrun in public sector construction projects in Nigeria." International Journal of Project Management, Vol. 8 No. 4, pp. 237241.

Duyshart, B., Walker, D., Mohamed, S., and Hampson, K. (2003). An example of developing a business model for information and communication technologies (ICT) adoption on construction projects-the National Museum of Australia project. Engineering, Construction and Architectural Management, Vol. 10 No. 3, pp. 179-192.

English, J. (2002), "The communication problems experienced by workforce on-site, and their possible solutions.” Journal of Construction Research, Vol. 3 No. 2, pp. 311-321.

Ejohwomu, O.A. and Oshodi, O.S. (2014), "A review of construction management and economics research outputs in Nigeria: towards a sustainable future." Journal of Construction Project Management and Innovation, Vol. 4 No. SP1, pp. 900-905.

Fan, L.C. and Fox, P.W. (2009), "Exploring Factors for Ethical Decision Making: Views from Construction Professionals." Journal of Professional Issues in Engineering Education and Practice, 10.1061/(ASCE)1052-3928(2009)135:2(60), pp. 60-69.

Franco, M. and Haase, H. (2010), "Failure factors in small and medium-sized enterprises: qualitative study from an attributional perspective." International Entrepreneurship and Management Journal, Vol. 6 No. 4, pp. 503-521.

Flyvbjerg, B., Holm, M.K.S. and Buhl, S.L. (2003), "How common and how large are cost overruns in transport infrastructure projects?” Transport reviews, Vol. 23 No. 1, pp. 71-88. 
Fugar, F. D. K., Ashiboe-Mensah, N. A., and Adinyira, E. (2013), "Human capital theory: implications for the Ghanaian construction industry development." Journal of Construction Project Management and Innovation, Vol. 3 No. 1, pp. 464-481.

Gil, N.A. (2010), "Language as a Resource in Project Management: A Case Study and a Conceptual Framework." IEEE Transactions on Engineering Management, Vol. 57 No. 3, pp. $450-462$.

Goh, C.H., Willy, S. and Low, S.P. (2005), "Factors affecting effective communication between building clients and maintenance contractors." Corporate Communications: An International Journal, Vol. 10 No. 3, pp. 240-251.

Golen, S.P., Catanach, A.H. and Moeckel, C. (1997), "The Frequency and Seriousness of Communication Barriers in the Auditor- Client Relationship." Business Communication Quarterly, Vol. 60 No. 3, pp. 23-37.

Goodwin, R.S.C. (1993), "Skills Required of Effective Project Managers." Journal of Management in Engineering, 10.1061/(ASCE)9742-597X(1993)9:3(217), pp. 217-226.

Gorse, C. A., and Emmitt, S. (2003), Investigating interpersonal communication during construction progress meetings: challenges and opportunities. Engineering, Construction and Architectural Management, Vol. 10 No. 4, pp. 234-244.

Gorse, C. A. and Emmitt, S. (2007), "Communication behaviour during management and design team meetings: a comparison of group interaction." Construction Management and Economics, Vol. 25 No. 11, pp. 1197-1213.

Gyekye, S. A. and Salminen, S. (2006), "The self-defensive attribution hypothesis in the work environment: Co-workers' perspectives." Safety science, Vol. 44 No. 2, pp. 157-168. 
Hair, J.F., Black W. C., Babin, B. J., Anderson, R.E. and Tatham R. L. (2010), Multivariate data analysis : a global perspective, 7th Ed., Pearson Education, Upper Saddle River, N.J.

Ho, R. (2014), Handbook of Univariate and Multivariate Data Analysis with IBM SPSS, 2nd Ed., CRC Press, Boca Raton.

Hon, C.K.H., Chan, A.P.C. and Yam, M.C.H. (2013), "Determining Safety Climate Factors in the Repair, Maintenance, Minor Alteration, and Addition Sector of Hong Kong.” Journal of Construction Engineering and Management, 10.1061/(ASCE)CO.1943-7862.0000588, pp. 519-528.

Jarkas, A. and Bitar, C. (2012), Factors Affecting Construction Labor Productivity in Kuwait. Journal of Construction Engineering and Management, 10.1061/(ASCE)CO.19437862.0000501, pp. 811-820.

Jeong, S.-H. (2009), "Public's Responses to an oil spill accident: A test of the attribution theory and situational crisis communication theory." Public Relations Review, Vol. 35 No. 3, pp. $307-309$.

Kaliba, C., Muya, M., and Mumba, K. (2009), "Cost escalation and schedule delays in road construction projects in Zambia." International Journal of Project Management, Vol. 27 No. 5, pp. 522-531.

Kelley, H. H. and Michela, J. L. (1980), "Attribution theory and research." Annual review of psychology, Vol. 31 No. 1, pp. 457-501.

Kwofie, T.E. (2015), Contribution of unique features of mass housing projects to project team communication performance. Unpublished $\mathrm{PhD}$ thesis. Kwame Nkrumah University of Science and Technology. 
Kwofie, T. E., Adinyira, E. and Fugar, F. D. K. (2015), “An empirical assessment of ineffective communication inherent in the attributes of mass housing projects." Journal of Construction Project Management and Innovation, Vol. 5 No. 2, pp. 1176-1195.

Laczniak, R.N., DeCarlo, T.E. and Ramaswami, S.N. (2001), “Consumers' Responses to Negative Word-of-Mouth Communication: An Attribution Theory Perspective." Journal of consumer Psychology, Vol. 11 No. 1, pp. 57-73.

Lalljee, M. (1987), Attribution theories and intercultural communication. In K. Knapp, W. Enninger, and A. Knapp-Potthof, eds. Analyzing intercultural communication. Mouton de Gruyter, New York, pp. 37-49.

Laryea, S. and Leiringer, R. (2012), Built environment research in West Africa: current trends and future directions In: Laryea, S., Agyepong, S.A., Leiringer, R. and Hughes, W. (Eds) Proc.s 4th West Africa Built Environment Research (WABER) Conference, 24-26 July 2012, Abuja, Nigeria, pp. 797-804.

Loosemore, M. and Lee, P. (2002), "Communication problems with ethnic minorities in the construction industry." International journal of project Management, Vol. 20 No. 7, pp. $517-524$.

Luo, L., Bippus, A. and Dunbar, N. E. (2005), "Causal attributions for collaborative public speaking presentations in college classes." Communication Reports, Vol. 18 No. 1-2, pp. $65-73$

Meng, X. (2012), "The effect of relationship management on project performance in construction.” International Journal of Project Management, Vol. 30 No. 2, pp. 188-198.

Naoum, S.G. (2007), Dissertation research and writing for construction students, 2nd Ed., 
Butterworth-Heinemann, Oxford ; Burlington, MA.

Ng, S. T., Skitmore, R. M., Lam, K. C., and Poon, A. W. (2004), "Demotivating factors influencing the productivity of civil engineering projects." International Journal of Project Management, Vol. 22 No. 2, pp. 139-146.

Ng, S.T., Eng Chen, S., McGeorge, D., Lam, K.C. and Evans, S. (2001), "Current state of IT usage by Australian subcontractors." Construction Innovation, Vol. 1 No. 1, pp. 3-13.

O’Connor, B.P. (2000), "SPSS and SAS programs for determining the number of components using parallel analysis and Velicer's MAP test." Behavior research methods, instruments, and computers, Vol. 32 No. 3, pp. 396-402.

Ochieng, E.G. and Price, A.D.F. (2010), "Managing cross-cultural communication in multicultural construction project teams: The case of Kenya and UK." International journal of project Management, Vol. 28 No. 5, pp. 449-460.

Oyediran, O. S. and Akintola, A. A. (2011), "A survey of the state of the art of e-tendering in Nigeria." Journal of Information Technology in Construction, Vol. 16, pp. 557-576.

Peansupap, V., and Walker, D. (2005). "Factors affecting ICT diffusion: a case study of three large Australian construction contractors." Engineering, Construction and Architectural Management, Vol. 12 No. 1, pp. 21-37.

Peterson, D. K., Kim, C., Kim, J. H. and Tamura, T. (2002), "The perceptions of information systems designers from the United States, Japan, and Korea on success and failure factors." International Journal of Information Management, Vol. 22 No. 6, pp. 421-439.

Pietroforte, R. (1997), “Communication and governance in the building process." Construction 
Management and Economics, Vol. 15 No. 1, pp. 71-82.

Plotnik, R. and Kouyoumdjian, H. (2011), Introduction to psychology, 9th Ed., Wadsworth/Cengage Learning, Belmont, CA.

Ramanathan, C., Narayanan, S.P. and Idrus, A.B. (2012), "Construction delays causing risks on time and cost - a critical review." Australasian Journal of Construction Economics and Building, Vol. 12 No. 1, pp. 37-57.

Rogoff, E. G., Lee, M. S. and Suh, D. C. (2004), “"Who done it?” Attributions by entrepreneurs and experts of the factors that cause and impede small business success." Journal of Small Business Management, Vol. 42 No. 4, pp. 364-376.

Savolainen, R. (2013), “Approaching the motivators for information seeking: The viewpoint of attribution theories." Library and Information Science Research, Vol. 35 No. 1, pp. 63-68.

Shehu, Z. and Akintoye, A. (2010), "Major challenges to the successful implementation and practice of programme management in the construction environment: A critical analysis." International Journal of Project Management, Vol. 28 No. 1, pp. 26-39.

Shohet, I.M. and Frydman, S. (2003), "Communication patterns in construction at construction manager level." Journal of Construction Engineering and Management, 10.1061/(ASCE)0733-9364(2003)129:5(570), pp. 570-577.

Standing, C., Guilfoyle, A., Lin, C. and Love, P. E. (2006), "The attribution of success and failure in IT projects. Industrial Management and Data Systems, Vol. 106 No. 8, pp. 11481165.

Stein, T., Frankel, R.M. and Krupat, E. (2005), "Enhancing clinician communication skills in a 
large healthcare organization: A longitudinal case study." Patient education and counseling, Vol. 58 No. 1, pp. 4-12.

Stewart, A. E. (2005), “Attributions of responsibility for motor vehicle crashes." Accident Analysis and Prevention, Vol. 37 No. 4, pp. 681-688.

Tai, S., Wang, Y. and Anumba, C.J. (2009). "A survey on communications in large-scale construction projects in China." Engineering, Construction and Architectural Management, Vol. 16 No. 2, pp. 136-149.

Thomas, S.R., Tucker, R.L. and Kelly, W.R. (1998), "Critical Communications Variables." Journal of Construction Engineering and Management, 10.1061/(ASCE)07339364(1998)124:1(58), pp. 58-66.

Tone, K., Skitmore, M. and Wong, J. K. W. (2009), “An investigation of the impact of crosscultural communication on the management of construction projects in Samoa." Construction Management and Economics, Vol. 27 No. 4, pp. 343-361.

Toor, S.-R. and Ogunlana, S.O. (2010). "Beyond the "iron triangle": Stakeholder perception of key performance indicators (KPIs) for large-scale public sector development projects.” International Journal of Project Management, Vol. 28 No. 3, pp. 228-236.

Ulang, N.M., Gibb, A.G.F. and Anumba, C.J. (2009), "Communication of health and safety information in construction", in: Dainty, A. (Ed.) proceedings of the 25th Annual ARCOM Conference in Nottingham, UK, 2009, Association of Researchers in Construction Management, pp. 1233-41.

Weiner, B., 1980. Human Motivation, Holt, Rinehart and Winston, New York. 
Weiner, B. (1985), "An attributional theory of achievement motivation and emotion." Psychological review, Vol. 92 No. 4, pp. 548-573

Wing, C.K., Raftery, J., and Walker, A. (1998). "The baby and the bathwater: Research methods in construction management." Construction Management and Economics, Vol. 16 No. 1, pp. 99-104.

Xie, C., Wu, D., Luo, J. and $\mathrm{Hu}, \mathrm{X}$. (2010), “A case study of multi-team communications in construction design under supply chain partnering." Supply Chain Management: An International Journal, Vol. 15 No. 5, pp. 363-370.

Yin, R.K., 1994. Case study research : design and methods 2nd Ed., Sage Publications. 
Table 1 Factors affecting effective communication in construction projects

\begin{tabular}{|c|c|}
\hline Author(s) & Factors identified in previous studies \\
\hline $\begin{array}{l}\text { Bowen and } \\
\text { Edwards (1996) }\end{array}$ & $\begin{array}{l}\text { Unclear definition of conditions in engagement letters and } \\
\text { service agreements; problems with client brief; and } \\
\text { asymmetry in cost planning information (i.e. difference } \\
\text { information received and how it is interpreted) }\end{array}$ \\
\hline
\end{tabular}

Thomas et al. (1998)

Carlsson et al. (2001)

Loosemore and

Lee (2002)

Goh et al. (2005)

Tai et al. (2009)

Tone et al. (2009)

Ulang et al. (2009) of time; and poor standards, quality, and health and safety

Accuracy of information received; procedures; barriers (interpersonal, accessibility, etc.); understanding of the information transmitted; timeliness; and completeness

Personal relations; type of project; project briefing; time; and expertise of project manager

Language

Differences in personality and interest; lack of checking information with users and craftsmen; use of inappropriate visualization techniques; insufficient resources- time and manpower; timing of information; work experiences; client's attitude; site constraints; cultural barriers; and organisational cultural barriers

Lack of good communication mechanisms; weak organizational structure of construction team; lack of uniform standards for construction information; and lack of support for advanced communication technologies

Poor work ethics, culture and practices; political and personal agendas; cultural beliefs and practices; concept

Geographical location; lots of paper work (formal communication process); work pressure due to high client expectations; and inadequate training in small construction firms

Ochieng and Price Trust; interpersonal skills; personal relationship; mutual (2010)

Xie et al. (2010) respect; language; clear lines of responsibility and clear robust issue resolution process.

Organisational structure/climate; interpersonal relationship; power difference; accessibility; common goal; and profit distribution

Kwofie (2015) Construction sites management styles, multiple geographical location for various schemes, network of procurement systems and repetitive tasks management delivery strategy
Type of project

Design phase of

construction projects

Construction projects

Construction industry

Building

Construction industry

Maintenance

Large-scale

construction projects

Cross-cultural communication in construction projects Health and Safety information in construction projects

Multicultural team working on heavy engineering projects

Design phase of projects

Mass housing project 
F7 Ineffective reporting system

F8 Limited resources

F9 Information filtering

F10 Conflicting business/industry ethics

F11 Lack of necessary skills

F12 Lack of trust

F13 Religious issues

F14 Language difficulties

F15 Age differences
Sources

Affare (2012), Goh et al. (2005), Tone et al. (2009)

Affare (2012), Bowen and Edwards (1996)

Affare (2012), Thomas et al. (1998)

Affare (2012), English (2002), Xie et al. (2010)

Affare (2012); English (2002), Goh et al. (2005), Tone et al. (2009)

Affare (2012), English (2002), Goh et al. (2005), Ochieng and Price (2010), Tai et al. (2009),

Affare (2012), Dawood and Sikka (2007), Tai et al. (2009),

Affare (2012), Goh et al. (2005), Tai et al. (2009)

Affare (2012), Thomas et al. (1998)

Affare (2012), Tone et al. (2009)

Affare (2012), Ulang et al. (2009

Affare (2012), Ochieng and Price (2010)

Affare (2012)

Affare (2012), Loosemore and Lee (2002), Ochieng and Price (2010)

Affare (2012); English (2002), Ochieng and Price (2010) 
Table 3 Barriers to effective communication in construction projects

\begin{tabular}{clccc}
\hline Label & Variable & Mean & Std. Deviation & Ranking \\
\hline F4 & Unclear objectives & 4.11 & 0.920 & 1 \\
F7 & Ineffective reporting system & 4.09 & .889 & 2 \\
F3 & Poor leadership & 4.00 & 1.083 & 3 \\
F11 & Lack of necessary skills & 3.98 & 1.119 & 4 \\
F6 & Unclear channels of communication & 3.86 & .943 & 5 \\
F8 & Limited resources & 3.74 & 1.021 & 6 \\
F2 & Poor listeners & 3.65 & 1.029 & 7 \\
F14 & Language difficulties & 3.63 & 1.220 & 8 \\
F9 & Information filtering & 3.62 & .838 & 9 \\
F12 & Lack of trust & 3.59 & 1.111 & 10 \\
F10 & Conflicting business/industry ethics & 3.50 & 1.124 & 11 \\
F1 & Political/community interference & 3.38 & 1.179 & 12 \\
F13 & Religious issues & 2.99 & 1.275 & 13 \\
F5 & Conflicting cultural values & 2.89 & 1.171 & 14 \\
F15 & Age differences & 2.10 & 1.150 & 15
\end{tabular}


Table 4 Comparison of eigenvalues from PCA and criterion values from Horn's parallel analysis.

\begin{tabular}{cccc}
\hline Component no. & Actual eigenvalue from PCA & Criterion value from parallel analysis & Decision \\
\hline 1 & 4.2992 & 1.887 & Accepted \\
2 & 2.216 & 1.669 & Accepted \\
3 & 1.506 & 1.516 & Rejected \\
4 & 1.147 & 1.391 & Rejected \\
5 & 1.103 & 1.289 & Rejected \\
\hline
\end{tabular}


Table 5 Results of PCA.

\begin{tabular}{lllc}
\hline Label & \multicolumn{1}{c}{ Factors/item components } & 1 & 2 \\
\hline \multicolumn{1}{c}{ Factor 1 (Managerial and technical) } & & \\
F1 & Political/community interference & 0.832 & \\
F2 & Poor listeners & 0.813 & \\
F3 & Poor leadership & 0.724 & \\
F4 & Unclear objectives & 0.722 & \\
F5 & Conflicting cultural values & 0.699 & \\
F6 & Unclear channels of communication & 0.550 & \\
F7 & Ineffective reporting system & 0.537 & \\
F8 & Limited resources & 0.519 & \\
F9 & Information filtering & 0.481 & \\
& Factor 2 (Credibility and background ) & & \\
F10 & Conflicting business/industry ethics & & 0.783 \\
F11 & Lack of necessary skills & & 0.667 \\
F12 & Lack of trust & & 0.620 \\
F13 & Religious issues & & 0.535 \\
F14 & Language difficulties & & 0.476 \\
F15 & Age differences & & 0.450 \\
& Eigenvalue & & \\
& \% of variance explained & & \\
\hline
\end{tabular}




\title{
Nigeria's construction industry: Barriers to effective communication
}

\begin{abstract}
Purpose - Communication plays an important role in the quality of the relationship, trust and collaboration among construction project teams. Literature suggests that effective communication is vital for achieving improved project performance. The aim here is to identify and assess the barriers to effective communication in the Nigerian construction industry, using attribution theory paradigm.
\end{abstract}

Design/methodology/approach - Questionnaires detailing 15 barriers to effective communication were administered to consultants and contractors engaged in the Nigerian construction sector. One hundred valid responses were analysed using mean score, factor analysis and factor score.

Findings - Unclear project objectives, ineffective reporting systems and poor leadership were ranked as the most significant barriers to effective communication. Factor analysis uncovered that the principal reasons responsible for ineffective communication include: managerial and technical barriers and credibility and background barriers.

Practical implications - The results provide information on barriers which needs to be addressed in order to improve communication in construction projects in Nigeria. There is a need to conduct post-completion reviews of construction projects so that project team members can learn and share knowledge on past experiences. Although the present study was conducted in the Nigerian context, it is envisaged that the research outcome will be widely applicable to other developing countries. 
Originality/value - The study provides insights on the perceived barriers to effective communication in Nigerian construction projects. The paper presents the direction for further research aimed at improving communication in construction projects in Nigeria.

Keywords Attribution theory, barriers, communication, construction industry, Nigeria, Organisation

Paper type Research paper

\section{INTRODUCTION}

Poor performance of construction projects remain a major problem in both developing and developed countries (Flyvbjerg et al., 2003). Almost every publication in the field of construction management reiterates this concern. Although Toor and Ogunlana (2010) have suggested the need to use other metrics (such as safety, stakeholder satisfaction, etc.) to evaluate performance of construction projects; cost, time and quality largely remains the most popular performance indicators. Despite the existence of several studies addressing poor performance of construction projects (AlSehaimi et al., 2013; Ramanathan et al., 2012), it is evident that this remains a re-occurring problem. Empirical evidence from a previous study suggests that ineffective communication among stakeholders is a significant factor responsible for poor performance of construction projects (Atkinson, 2002; $\mathrm{Ng}$ et al., 2004). In a similar vein, Meng (2012) found that improved communication amongst stakeholders is vital to meeting project performance objectives. Hence, an understanding of communication practice within the construction industry is an important element in the process of improving performance of construction projects. The present research effort focuses on gaining insights into the factors responsible for ineffective communication in the Nigerian construction industry.. 
In recent years, researchers in the field of construction management have shown an increased interest in communication-related studies. Trade liberalization and the need to exploit markets in foreign countries have created new communication problems in the construction industry which arise due to multi-cultural work environment (Loosemore and Lee, 2002; Ochieng and Price, 2010). Other studies have investigated the use of Information and Communication Technology (ICT) in the construction industry (Duyshart et al., 2003; Ng et al., 2001; Peansupap and Walker, 2005); communication between design team and construction manager (Shohet and Frydman, 2003); and communication practice in construction projects (Gorse and Emmitt, 2003; Tai et al., 2009). There is limited evidence of studies addressing communication problems in the construction industry in Africa (Ejohwomu and Oshodi, 2014; Laryea and Leiringer, 2012); except for Kwofie et al. (2015) which addresses ineffective communication in mass housing projects in Ghana. Also, lack of studies focused on communication in project management literature has been linked to project failures (Dainty et al., 2006; Akintoye and Shehu, 2010). Using the lens of attribution theory, the present study examines what construction professionals attribute to as the barriers to effective communication in projects. Hence, the following objectives are addressed: (1) to identify the barriers to effective communication in construction projects; and (2) to assess the barriers to effective communication in construction projects.

The remainder of this report is structured into four sections. First, a review of literature, attribution theory and theoretical framework is presented in the next section. The underlying science that guides the choice of research method and the procedures of conducting the study is explained in the research methods section. This is preceded by data analysis in section three and findings of cross-sectional survey on communication practices in section four. 


\section{REVIEW OF LITERATURE}

\section{Barriers to effective communication in the construction industry}

Effective communication between construction project stakeholders (client, contractors, suppliers, users, etc.) is central to achieving improved performance of construction projects. Generally, there is no accepted definition for 'communication' as the term can be viewed from various perspectives. Dainty et al. (2006) describes effective communication as a process whereby feedback is received for information that is transmitted. Furthermore, Dainty et al. (2006) points out that as the construction industry moves towards a largely service oriented industry (most of the production activities are outsourced); there is a need for effective communication to improve knowledge sharing, collaboration and integrate all individuals involved in the construction process. This will improve project performance and serve as a feedback process to drive improvements in the construction sector. It is worth mentioning that communication takes place not only between individuals involved in a construction project, but also among organisations. Understanding the barriers to effective communication is crucial to improving the process of communication during construction projects.

As evident from literature, effective communication is vital for trust, collaboration, and improved performance of construction projects (Bond-Barnard et al., 2013). From a normative view point, a number of studies have explored significant factors that affects the effectiveness of communication among construction project team and stakeholders. Gil (2010) utilised a case study approach to evaluate how changes in tone (language) affect communication in a construction project. Carlsson et al. (2001) sought to investigate factors affecting communication, communication patterns, reasons for communication and communication 
methods. It was found that project type, project briefing and time are major factors that reduce the effectiveness of communication in construction projects. Similarly, Pietroforte (1997) proposed a framework for analysing the contractual process and information requirement in the building process. It was revealed that differences in the perception of project team members and nature of information affects information flow. Research also showed that differences in personality and interest, lack of checking information with users and craftsmen, use of inappropriate visualization techniques, insufficient resources (time and manpower), timing of information, work experiences, client's attitude, site constraints, cultural barriers and organisational cultural barriers were factors affecting effective communication between clients and maintenance contractors (Goh et al., 2005). Table 1 provides a summary of previous studies on this research topic.

\section{'Insert Table 1 here'}

As can be seen in Table 1, a large majority of the studies were conducted in developed countries, except for two studies which focused on Kenya and United Kingdom (Ochieng and Price, 2010) and Ghana (Kwofie et al., 2015). For example, factors affecting communication in construction projects in Australia (Loosemore and Lee, 2002); Singapore (Loosemore and Lee, 2002; Goh et al., 2005); and United States of America (Thomas et al., 1998). A difference was found to exist in communication patterns utilized in heavy engineering projects executed in Kenya and UK (Ochieng and Price, 2010). This suggests that the findings of studies conducted in the developed world may not be generalizable to developing countries. This indicates a need to understand the perception of construction professionals on factors affecting the effectiveness of communication in the context of developing countries. The present study reported here addresses this gap that exists in literature. 


\section{Theoretical framework}

Every construction project is characterized by their unique nature, have pre-defined performance goals; involves multiple project stakeholders; entails different project phases (preplanning, execution and post-construction); and the execution phase is complex. As different phases of the project involve several academic disciplines (e.g. engineers, architects, etc.) of diverse culture and background; there is need for effective communication among project participants. As shown in the preceding sections of this paper, communication significantly affects the chances of meeting pre-planned project objectives, and thus must be properly managed. Therefore, attribution theory is used in this study to address questions relating to barriers to effective communication among contracting parties, this is essential for improving project outcomes.

\section{Attribution theory}

As stated in the preceding section; the origins of ineffective communication in construction projects have various root causes. Attribution theory is principally concerned with how people interpret information in order to determine the causes of an event. Reactions to similar events are influenced by causal attribution attached by individuals (Kelley and Michela, 1980; Savolainen, 2013). Although attribution theory has been utilized in several studies in the field of psychology, it has also been found useful in communication-related studies (see Lalljee, 1987; Laczniak et al., 2001; Jeong, 2009). Attribution theory was chosen for application to explain the barriers to effective communication in the present study for two reasons. First, the theory helps to achieve "cognitive control" needed to explain factors giving rise to ineffective communication. Second, two important features of ineffective communication are: they are 
unanticipated and have negative impact. There are key questions that attribution theory seeks to address by identifying the cause of an event (Weiner, 1985; Kelley and Michela, 1980). Kelley and Michela (1980) classified studies that have applied attribution theory into two groups based on focus: casual attribution (i.e. studies focused on explaining perceived cause of an event) and consequence (studies that measure impact of causes on outcome). The present study focuses on causal attribution. Thus, attribution theory plays an important role in explaining the factors that construction firms perceive as barriers to effective communication in projects.

Causal attributions have been categorised into two distinct groups: internal and external. Internal attribution refers to inferences which are made based on factors that an individual has control over (e.g. personality traits, motives, etc.); and external attribution are inferences which evolve from issues over which a person has little or no control (Plotnik and Kouyoumdjan, 2011). Results emanating from previous studies have shown that people tend to associate success with internal attribution; however, failure is linked to external attribution (Franco and Haase, 2010; Luo et al., 2005; Peterson et al., 2002). Attribution theorists term this behaviour as 'selfserving' bias. The finding of some studies (such as Brubaker, 1988) do not agree to this. This is referred to as 'self-effacing' bias. In addition, empirical evidence revealed that there are differences in the perception of actors and observers about the cause of an event (Rogoff et al., 2004; Stewart, 2005). Despite these limitations, Kelley and Michela (1980) acknowledges that attribution theory has provided 'meaningful' answers that addresses causal attribution problems.

Notably, attribution theory has been applied in construction-related studies. The theory has been applied to explain factors responsible for occurrence of human errors (Atkinson, 1998); nail gun injury (Albers et al., 2014) and effectiveness of communication in mass housing projects (Kwofie et al., 2015). It was found that supervisors attributed human errors in construction 
projects to external attribution (Atkinson, 1998). Poor formal communications is principally responsible for errors, which leads to defects in construction projects (Atkinson, 2002). Risk associated with tools, unsafe behaviours and work pressures were identified as important factors responsible for nail injuries (Albers et al., 2014). Finally, Kwofie et al. (2015) classified factors responsible for ineffective communication into three groups namely: access to information challenges, challenges in flow of information and component; and import of information challenges. Based on the foregoing, it is reasonable to suggest that attribution theory is useful in explaining the cause of an event. Identifying the causal attribution associated with the occurrence of an event is crucial to developing and implementing response strategies in the future. The present study extends the work into ineffective communication in construction projects in developing countries which has been acknowledged as an important problem. Hence, the attributions linked with ineffective communication are examined.

\section{RESEARCH METHOD}

To date, various methods have been used to investigate communication problems in the field of construction management. Dainty (2008) categorized research approaches utilized in construction management studies into four groups namely quantitative, qualitative, mixed and review. The factors that affects choice and suitability of a particular research method are largely dependent on the research situation and research problem (Yin, 1994; Wing et al., 1998). The need to compare and replicate, maintain low interference between researcher and participants, objective measurement of the phenomenon been studied, objective assessment of reliability of validity of findings, generalization of findings and testing of a hypothesis are key strengths of the 
quantitative approach (Amaratunga et al., 2002; Wing et al., 1998). A questionnaire survey approach was chosen because it is suitable for collecting data from a large group of respondents (i.e. contractors, clients and consultants). This approach has also been used in similar previous studies (see Shohet and Frydman, 2003; Thomas et al., 1998) found in literature.

A modified questionnaire used in a similar previous work (Affare, 2012) was used in the present study. The questionnaire was modified based on other barriers identified from the review of literature. Pilot surveys and feedback from this process (i.e. feedback from the respondents of the pilot survey) ensured that the barriers in the Nigerian context are properly captured. The final list of 15 barriers to effective communication in construction projects in Nigeria formed the main content of the questionnaire design (see Table 2). The respondents were asked to evaluate the degree to which each item was a barrier to effectiveness of communication using a five-point Likert scale in which ranged from ' $5=$ strongly agree to $1=$ strongly disagree'. In addition, an open-ended question was added to the questionnaire so as to identify the most preferred medium of communication in construction projects

A total of 200 questionnaires were administered to construction firms operating in Nigeria. The sample for the study was purposively drawn from over 400 organizations registered with Association for Consulting Engineering in Nigeria (ACEN), Federation of Construction Industry (FOCI), Quantity Surveyors Registration Board of Nigeria (QSRBN), Architects Registration Council of Nigeria (ARCON) and large client organisations (private and government departments in charge of procuring construction projects). Purposive sampling ensured that the respondents are employed in organisations currently handling at least one or more construction project(s). This is to adequately capture the barriers in the context of current happenings in the Nigerian construction sector. 
Out of the 200 questionnaires distributed, 100 were received and valid for further analysis. Out of the 100 respondents, $20 \%$ were engaged in private client organisations, $34 \%$ contracting firms, $18 \%$ consulting firms, and $28 \%$ public client organisations. In terms of respondents' years of experience, $71 \%$ had over 5 years of experience. This indicates that a good spread of different professional with varying background and long years of experience are represented in the survey.

Cronbach's alpha coefficient is a measure used to determine internal consistency. In this study, the value of Cronbach's alpha coefficient test was 0.774. This suggests that the responses obtained based on the five-point Likert scale can are reasonably reliable.

\section{$\underline{\text { Tools for data analysis }}$}

Mean Score

Cheung et al. (2010) used "mean score" as a tool to determine the rank of "attractive" and "negative" factors for adopting the use of PPP in projects as suggested by respondents in Hong Kong and Australia. The data collected from the current survey was analysed using the same technique. Detailed description of the process of calculating mean scores can be found in Cheung et al. (2010). Responses received based on the five-point Likert scale (described earlier) was used to calculate the mean score for each barrier. The mean score served as a metrics for ranking $\underline{\text { the barriers. }}$

\section{Factor analysis}

Exploratory factor analysis (EFA) is a technique used to reduce the number of variables into a smaller and meaningful number of factors (Ho, 2014). Principal component 


\section{DATA ANALYSIS AND DISCUSSION}

\section{Ranking of the barriers to effective communication}

The mean values and standard deviation of the barriers to effective communication served as a basis for ranking in the order of significance. As shown in Table 3, the top 5 ranked barriers influencing effective communication in Nigerian construction projects include: (1) unclear objectives; (2) ineffective reporting system; (3) poor leadership; (4) lack of necessary skills; and (5) unclear channels of communication. However, religious issues, conflicting cultural values, and age differences were the least ranked barriers to effective communication. 
The results of the current study are in line with those of previous studies (Daim et al., 2012; Golen et al., 1997; Tai et al., 2009). The finding of Daim et al. (2012) showed that trust, interpersonal relations, cultural differences, leadership and technology are major causes of communication breakdown among global virtual teams (Daim et al., 2012). Also, the causes of communication problems in large scale construction projects in China are: lack of goød communication mechanism, weak organizational structures of construction teams, lack of uniform standards for construction information, and lack of support for advanced communication technologies (Tai et al., 2009). Similarly, Similarly, Golen et al. (1997) found that distertion/omission of information, lack of credibility, lack of trust, hostile attitude and inadequate common accounting knowledge are barriers to communication between client and auditor. It is imperative to note that trust and personal attributes were the most significant factors identified in Golen et al. (1997), this differs from the results of the present study reported here. This inconsistency may be due to differences in characteristics of respondents surveyed. It can therefore be suggested that clearly defined objectives; adopting and implementing an effective mechanism for reporting progress in projects; providing strong leadership; training and retraining construction professionals on effective communication skills; and development of clearly defined eommunication channels among project stakeholders are crucial actions needed to improve the effectiveness of communication in construction projects.

\section{'Insert Table 3 here'}

\section{Underlying Dimension of Barriers to Effective Communication - Factor analysis}

Exploratery factor analysis (EFA) is a technique used to reduce the number of variables into a smaller and meaningful number of factors (Ho, 2014). Principal component analysis (PCA) was utilised, this is because of its wide application (Hon et al., 2013). Two tests, Kaiser- 


\section{'Insert Table 4 here'}

As a rule of the thumb, the factor loadings which range between $0.3-0.4$ are considered to be within the acceptable proposed threshold (Hair et al., 2010). In the present study, the factor loading was set at 0.4 in the Statistical Package for the Social Sciences (SPSS) software and all loading above the set value are retained. The next challenge is to determine the number of the factors to be extracted. To achieve this, three different test were considered which include Kaiser's criterion, scree test and parallel analysis. With the aid of parallel analysis which is considered as the most accurate approach (O'Connor, 2000), the number of factor to be extracted was determined. By comparing the results of the actual eigenvalue from PCA (SPSS output) with those of parallel analysis (see Table 4), the value obtained from SPSS must be greater than the criterion value in order to accept.

\section{'Insert Table 4 here'}

The two-component solutions that encapsulated the 15 variables explaining a total variance of $43.39 \%$ are listed as follows (Table 5): 
- Managerial and technical barriers: this factor consisted of 9 items and $28.62 \%$ of the total variance. Some of the items were related to managerial issues (F3, F5, F6, and F8). Other variables were related to technical or expertise issues (F1, F2, F4, F7, and F9).

- Credibility and background barriers: this factor was composed of six items, explaining $14.78 \%$ of the total variance. This factor described what individuals and/or group individual value and experienced.

\section{'Insert Table 5 here'}

The factor loadings explain the correlation among the variables in a factor component. Fan and Fox (2009) affirm that this does not highlight the significance of the factor. To address this concern, the relative importance of the factors extracted (see Table 5) is determined by using factor scores (Fan and Fox, 2009). The formula for factor scores is expressed in Equation 1 below.

$$
F i=\frac{\sum_{j=1}^{n} A i j}{n}
$$

Where $F i=$ factor score; $A i j=$ mean score of the $j$ th attribute of factor; $i$ and $n=$ the number of attributes associated with the factor.

Using the mean score of each item that relates to each factor to compute a factor score, it was revealed that 'managerial and technical' factor ranked highest with a factor score of 3.77 and the lowest ranked is 'credibility and background' factor (factor score $=3.20$ ).

\section{DISCUSSION OF FINDINGS}




\section{Discussion of mean score results}

The results of the current study are in line with those of previous studies (Daim et

al., 2012; Golen et al., 1997; Tai et al., 2009). The finding of Daim et al. (2012) showed that $\underline{\text { trust, interpersonal relations, cultural differences, leadership and technology are major causes of }}$ communication breakdown among global virtual teams (Daim et al., 2012). Also, the causes of communication problems in large scale construction projects in China are: lack of good communication mechanism, weak organizational structures of construction teams, lack of $\underline{\text { uniform standards for construction information, and lack of support for advanced communication }}$ technologies (Tai et al., 2009). Similarly, Similarly, Golen et al. (1997) found that distortion/omission of information, lack of credibility, lack of trust, hostile attitude and inadequate common accounting knowledge are barriers to communication between client and auditor. It is imperative to note that trust and personal attributes were the most significant factors identified in Golen et al. (1997), this differs from the results of the present study reported here. This inconsistency may be due to differences in characteristics of respondents surveyed. It can $\underline{\text { therefore be suggested that clearly defined objectives; adopting and implementing an effective }}$ mechanism for reporting progress in projects; providing strong leadership; training and retraining construction professionals on effective communication skills; and development of clearly defined communication channels among project stakeholders are crucial actions needed to improve the effectiveness of communication in construction projects.

\section{Discussion of factor analysis results}

Understanding the barriers to effective communication on construction projects is important to improving project performance. This study reports those communication barriers perceived by construction professionals as detrimental to the relationship among construction 
project teams. These barriers as identified from an initial literature review (used in developing survey instrument) and ranked based on the perceptions of the respondents were categorized into two main groups. In essence, these two factors are believed to be the factors inhibiting communication in construction organisations and focusing on these major factors will lead to an improvement in the effectiveness of communication. Details of the factors are discussed in the next subsections.

\section{Factor 1: Managerial and technical factor}

The "managerial and technical" factor encapsulates nine barriers: (1) political/community interference, (2) poor listeners, (3) poor leadership, (4) unclear objectives, (5) conflicting cultural values, (6) unclear channels of communication, (7) ineffective reporting system, (8) limited resources and (9) information filtering. The factor accounts for $28.62 \%$ of the total variance explained among all the barriers (Table 5).

Many studies have demonstrated that issues relating to management and technical factors are critical to improving the effectiveness of communication in construction projects. Bowen and Edwards' (1996) exploratory study on effectiveness of cost plan communication at the design stage of building project revealed that improvements can be achieved by ensuring that project document (engagement letters and service agreements) are worded in explicit terms. In a similar vein, findings from Goh et al. (2005) identified that 'lack of checking information with users and craftsmen 'and 'use of inappropriate visualization' are critical barriers to effective communication in building maintenance projects. Dawood and Sikka (2007) conducted experiments using 4D models and 2D CAD (computer-aided design) drawings. Communication, coordination and retention of information were more effective in the group that used 4D models when compared with the 2D group. Also, it was found that client high expectations, government regulations and 
inadequate training for small construction firms are critical challenges to communication of health and safety information at design stage of construction projects. The results emanating from these studies highlight the importance of managerial and technical issues.

In dealing with managerial and technical barriers, efforts should be directed towards adequate briefing of all stakeholders (contractors, client, consultants and others) of the intended objectives of a construction project at the inception. In addition, there is a need to adopt the use of new visualization technologies, such as building information modelling (BIM), in the process of managing the design and execution phases of construction projects. This will ensure that all project stakeholders get a better visual representation of the information been transmitted and respond in a way that meets the need of the information sender. Most of the items under this barrier category can be addressed by the client and its representative (i.e. the consultants) by providing leadership and adequate feedback mechanism towards improving the effectiveness of communication among different individuals involved in construction projects.

\section{Factor 2: Credibility and background factor}

This factor consist of six barriers related to 'credibility and background' in Nigerian construction projects: (1) conflicting business/industry ethics, (2) lack of necessary skills, (3) lack of trust, (4) religious issues, (5) language difficulties, and (6) age differences. This factor accounts for $14.78 \%$ of variance explained among all barriers (Table 5).

According to Dada and Jagboro (2007), the traditional method is the most used in procuring construction projects in Nigeria. In the traditional procurement process, project teams are formed on an ad-hoc basis. Gorse and Emmitt (2007) found that 'work environment' and 'working relationship' among project teams has an influence on the effectiveness of 
communication. English (2002) conducted cross-cultural training with workers in the construction industry of South Africa, and found that the training resulted in improvements in communication and cooperation. Empirical evidence has shown the importance of skills in improving the effectiveness of communication (Goodwin, 1993; Bowles et al., 2001; Stein et al., 2005).

In the Nigerian construction sector, a large majority of construction professionals and client still prefer the traditional procurement system. The use of partnering and other forms of relational contracting methods is still unpopular, despite reported benefits in previous studies. 'Improved relationship amongst project participants', 'improved communication amongst project participants' and 'more responsive to the short-term emergency, changing project or business needs' are regarded as the most important benefits of partnering in construction projects (Chan et al., 2003). Based on the foregoing, it is evident that there is a need for training and retraining Nigerian construction professionals in the areas related to ethics, managing different cultures in project teams and application of relational contracting.

\section{Attribution dimensions}

To determine if the 15 barrier items could be reduced into meaningful factors, factor analysis (Table 5) was conducted on the responses obtained from the survey. The first cluster consists of nine barrier items relating to management and technical issues. The second component consists of six items and was labelled as credibility and background factor. The credibility and background factor was considered as internal attribution (i.e. barriers that are within the control of construction professionals). However, management and technical factor 
were considered as external attribution. This is because construction professionals do not necessarily have control over these barriers.

Based on the factor score (which was computed using mean score of the barrier items in each factor group), the 'managerial and technical barriers' factor were rated higher than the 'credibility and background' factor. This shows that the external attribution was rated relatively higher than internal attribution as factors which act as barriers to effective communication in construction projects. Hence, it is reasonable to suggest that the responses to the survey exhibit self-serving bias. There are no previous studies focused on Nigeria to compare the findings of the present research with. However, the findings are consistent with those obtained by Gyekye and Salminen (2006), it was found that witness (workers) of industrial accidents linked event causality more with external attributions. A possible explanation for this might be that construction professionals in Nigeria exhibit defensive behaviour so as not to be held culpable for failure (i.e. unsuccessful outcome of an event). This line of argument is supported by assertions found in Dlakwa and Culpin (1990) study on causes of overrun in government-funded projects in Nigeria. The need for government to take proactive action aimed at improving project outcomes was recommended (Dlakwa and Culpin, 1990). It can therefore be assumed that construction professionals are more likely to assign unsuccessful outcomes to external attribution.

\section{SIGNIFICANCE, LIMITATIONS AND AREAS FOR FURTHER RESEARCH}

Previous studies have shown that identifying significant factors causing a problem is critical to improving professional practice in the industry (see Hon et al., 2013; Jarkas and Bitar, 
2012). Effective communication is beneficial to various stakeholders involved in construction projects. The present study focuses on examining the barriers to effective communication. Fifteen barriers to effective communication were identified and the importance of each examined via a cross-sectional survey. The research findings provide stakeholders (i.e. clients, consultants and contractors) with valuable insights needed to overcome these barriers and improve communication in Nigerian construction projects.

Despite the importance of the findings of the present study, it is important to note that the generalizability of the result is limited. Questionnaire surveys always entail the risk of respondent's bias, sampling approach and imprecise definition. However, it is assumed that purposively selecting respondent will minimize these limitations. Also, the numbers of response from the consultant group is relatively small. It may be viewed that there is an overreliance on the perception of client organisations. The effects of these limitations can be addressed by taking a larger sample size in future studies. In future investigations, it might be possible to use a combination of quantitative and qualitative research methods. This would provide deeper insights into the impact of characteristics of respondents (such as years of experience; position with organisation, etc.) on factors consideredattributed_as barriers to effective communication in construction projects.

\section{CONCLUSIONS AND RECOMMENDATIONS}

In order to identify and assess the barriers to effective communication among project teams within the construction industry, a cross-section survey was conducted. Previous studies found in construction management literature affirm that effective communication among project team will result in improved project outcomes. In addition, very little is known about barriers to 
communication in developing counties. The present study addresses the gap in knowledge by examining barriers to effective communication in the Nigerian construction industry using attribution theory paradigm.

The study has identified 'unclear objectives', 'ineffective reporting system' and 'poor leadership' are the main barriers to effective communication in Nigerian construction projects. Using factor analysis, the underlying relationships among the 15 barriers were further explored. The barriers are categorised into two groups: managerial and technical (external attribution) factor and credibility and background (internal attribution) factor. Interestingly, 'self-serving' bias was observed in the responses collected from the survey. The findings of this study provide some practical implications, especially for stakeholders in the Nigerian construction industry (contractors, consultants, client, academics, etc.). Self-serving bias implies that construction professionals will associate ineffective communication with external attribution (i.e. causes of ineffective communication are beyond their control). This suggest that Nigerian construction professional will fail to learn from experience partly due to self-serving bias. Thus, they may continue using the same process and techniques, regardless of whether or not they are effective.

Overall, the findings of the study suggest there is a need for post-completion review of construction projects. As suggested in Standing et al. (2006), when formal evaluation of project teams are not done, there is a high likelihood that team members will attribute performance of project wrongly. This can be achieved through enlightenment programmes targeted at informing stakeholders of the importance and accruable benefits of conducting a formal review of completed projects. In addition, there is a need to encourage the use of relational contracting as suggested earlier in the body of this paper. 
Although the geographical scope of the present study is limited to Nigeria, the findings can be extrapolated to the construction industry in any other developing country. Barriers to communication effectiveness in Nigerian construction projects tend to be context-specific and unique. However, certain generic practices in the Nigerian construction sector project in Nigeria are likely to be occur in other developing countries toøas well. As a developing country, j]ob characteristics, work environments and societal problems experienced are typical examples of common features that might exist in the within the-construction industry of in Nigeria are likely to be similar to those in other-developing countriescountries societies, (such as Ghana, Egypt and Zambia). A critical look at previous studies on Nigeria, Egypt and Zambia reveals that finance-related factors are significant causes of poor performance of construction projects (Abd El-Razek et al., 2008; Aibinu and Odeyinka, 2006; Kaliba et al., 2009). Also, the low use of information and communication technology is observed in the Nigerian and Ghanaian construction sector (see Oyediran and Akintola, 2011; Fugar et al., 2013). The findings that emerge from these previous studies show that the challenges faced by the construction sector of developing countries are largely similar. Therefore, it is reasonable to suggest that The findings of these studies highlights that the challenges in the construction sector of developing countries are largely similar. Therefore, the barriers to effective communication derived from the Nigeria construction industry would be relevant in in Nigeria would be relevant and of value to other developing countries.as well.

\section{REFERENCES}

Abd El-Razek, M., Bassioni, H. and Mobarak, A. (2008), "Causes of Delay in Building Construction Projects in Egypt." Journal of Construction Engineering and Management, 10.1061/(ASCE)0733-9364(2008)134:11(831), pp. 831-841. 
Affare, M. A. W. (2012), An assessment of project communication management on construction projects in Ghana, Unpublished Master's thesis. Kwame Nkrumah University of Science and Technology.

Aibinu, A. and Odeyinka, H. (2006), "Construction Delays and Their Causative Factors in Nigeria." Journal of Construction Engineering and Management, 10.1061/(ASCE)07339364(2006)132:7(667), pp. 667-677.

Albers, J. T., Hudock, S. D., and Lowe, B. D. (2014), "Residential building stakeholders' attitudes and beliefs regarding nail gun injury risks and prevention." New solutions: a journal of environmental and occupational health policy, Vol. 23 No. 4, pp. 577-605.

AlSehaimi, A., Koskela, L., and Tzortzopoulos, P. (2013). "Need for Alternative Research Approaches in Construction Management: Case of Delay Studies.” Journal of Management in Engineering, 10.1061/(ASCE)ME.1943-5479.0000148, pp. 407-413.

Amaratunga, D., Baldry, D., Sarshar, M. and Newton, R. (2002), "Quantitative and qualitative research in the built environment: application of "mixed" research approach." Work study, Vol. 51 No. 1, 17-31.

Atkinson, A. (1998), "Human error in the management of building projects." Construction Management and Economics, Vol. 16 No. 3, pp. 339-349.

Atkinson, A. R. (2002), "The pathology of building defects; a human error approach." Engineering Construction and Architectural Management, Vol. 9 No. 1, pp. 53-61.

Bond-Barnard, T.J., Steyn, H. and Fabris-Rotelli, I. (2013), "The impact of a call centre on communication in a programme and its projects." International Journal of Project Management, Vol. 31 No. 7, pp. 1006-1016. 
Bowen, P. A. and Edwards, P. J. (1996), “Interpersonal communication in cost planning during the building design phase." Construction Management and Economics, Vol. 14 No. 5, pp. 395-404.

Bowles, N., Mackintosh, C. and Torn, A. (2001), "Nurses' communication skills: an evaluation of the impact of solution-focused communication training." Journal of Advanced Nursing, Vol. 36 No. 3, pp. 347-354.

Brubaker, B. H. (1988), “An attributional analysis of weight outcomes.” Nursing research, Vol. 37 No. 5, 282-289.

Canales, A., Arbelaez, M., Vasquez, E., Aveiga, F., Strong, K., Walters, R., Jaselskis, E., and Jahren, C. (2009), "Exploring Training Needs and Development of Construction Language Courses for American Supervisors and Hispanic Craft Workers." Journal of Construction Engineering and Management, 10.1061/(ASCE)0733-9364(2009)135:5(387), pp. 387-396.

Carlsson, B., Josephson, P.E. and Larson, B. (2001), "Communication in building projects: empirical results and future needs." In: CIB World Building Congress: Performance in Product and Practice, 2-6 April. Wellington, New Zealand.

Chan, A.P.C., Chan, D. W., and Ho, K. S. (2003), "An empirical study of the benefits of construction partnering in Hong Kong." Construction Management and Economics, Vol. 21 No. 5, pp. 523-533.

Cheung, E., Chan, A. P.C., and Kajewski, S. (2010), "Suitability of procuring large public works by PPP in Hong Kong." Engineering, Construction and Architectural Management, Vol. 17 No. 3, pp. 292-308.

Chan, C.T.W. (2012), “The principal factors affecting construction project overhead expenses: 
an exploratory factor analysis approach." Construction Management and Economics, Vol. 30 No. 10 , pp. 903-914.

Dada, J. O. and Jagboro, G. O. (2007). "An evaluation of the impact of risk on project cost overrun in the Nigerian construction industry." Journal of Financial Management of Property and Construction, Vol. 12 No. 1, pp. 37-44.

Daim, T.U., Ha, A., Reutiman, S., Hughes, B., Pathak, U., Bynum, W. and Bhatla, A. (2012), "Exploring the communication breakdown in global virtual teams." International Journal of Project Management, Vol. 30 No. 2, pp. 199-212.

Dainty, A. (2008), Methodological pluralism in construction management research. In A. Knight and L. Ruddock, eds. Advanced research methods in the built environment. John Wiley and Sons, United Kingdom, pp. 1-13.

Dainty, A., Moore, D. and Murray, M. (2006), Communication in Construction: Theory and Practice, Taylor and Francis, London.

Dawood, N. and Sikka, S. (2007), "Measuring the effectiveness of 4D planning as a valuable communication tool", in Boyd, D. (Ed.) proceedings of the 23rd Annual ARCOM Conference in Belfast, UK, 2007, Association of Researchers in Construction Management, pp. $451-460$.

Dlakwa, M. M. and Culpin, M. F. (1990), "Reasons for overrun in public sector construction projects in Nigeria." International Journal of Project Management, Vol. 8 No. 4, pp. 237241.

Duyshart, B., Walker, D., Mohamed, S., and Hampson, K. (2003). An example of developing a business model for information and communication technologies (ICT) adoption on 
construction projects-the National Museum of Australia project. Engineering, Construction and Architectural Management, Vol. 10 No. 3, pp. 179-192.

English, J. (2002), “The communication problems experienced by workforce on-site, and their possible solutions.” Journal of Construction Research, Vol. 3 No. 2, pp. 311-321.

Ejohwomu, O.A. and Oshodi, O.S. (2014), "A review of construction management and economics research outputs in Nigeria: towards a sustainable future." Journal of Construction Project Management and Innovation, Vol. 4 No. SP1, pp. 900-905.

Fan, L.C. and Fox, P.W. (2009), "Exploring Factors for Ethical Decision Making: Views from Construction Professionals." Journal of Professional Issues in Engineering Education and Practice, 10.1061/(ASCE)1052-3928(2009)135:2(60), pp. 60-69.

Franco, M. and Haase, H. (2010), "Failure factors in small and medium-sized enterprises: qualitative study from an attributional perspective." International Entrepreneurship and Management Journal, Vol. 6 No. 4, pp. 503-521.

Flyvbjerg, B., Holm, M.K.S. and Buhl, S.L. (2003), "How common and how large are cost overruns in transport infrastructure projects?" Transport reviews, Vol. 23 No. 1, pp. 71-88.

Fugar, F. D. K., Ashiboe-Mensah, N. A., and Adinyira, E. (2013), "Human capital theory: implications for the Ghanaian construction industry development." Journal of Construction Project Management and Innovation, Vol. 3 No. 1, pp. 464-481.

Gil, N.A. (2010), "Language as a Resource in Project Management: A Case Study and a Conceptual Framework." IEEE Transactions on Engineering Management, Vol. 57 No. 3, pp. $450-462$. 
Goh, C.H., Willy, S. and Low, S.P. (2005), "Factors affecting effective communication between building clients and maintenance contractors." Corporate Communications: An International Journal, Vol. 10 No. 3, pp. 240-251.

Golen, S.P., Catanach, A.H. and Moeckel, C. (1997), "The Frequency and Seriousness of Communication Barriers in the Auditor- Client Relationship." Business Communication Quarterly, Vol. 60 No. 3, pp. 23-37.

Goodwin, R.S.C. (1993), "Skills Required of Effective Project Managers." Journal of Management in Engineering, 10.1061/(ASCE)9742-597X(1993)9:3(217), pp. 217-226.

Gorse, C. A., and Emmitt, S. (2003), Investigating interpersonal communication during construction progress meetings: challenges and opportunities. Engineering, Construction and Architectural Management, Vol. 10 No. 4, pp. 234-244.

Gorse, C. A. and Emmitt, S. (2007), "Communication behaviour during management and design team meetings: a comparison of group interaction." Construction Management and Economics, Vol. 25 No. 11, pp. 1197-1213.

Gyekye, S. A. and Salminen, S. (2006), "The self-defensive attribution hypothesis in the work environment: Co-workers’ perspectives." Safety science, Vol. 44 No. 2, pp. 157-168.

Hair, J.F., Black W. C., Babin, B. J., Anderson, R.E. and Tatham R. L. (2010), Multivariate data analysis : a global perspective, 7th Ed., Pearson Education, Upper Saddle River, N.J.

Ho, R. (2014), Handbook of Univariate and Multivariate Data Analysis with IBM SPSS, 2nd Ed., CRC Press, Boca Raton.

Hon, C.K.H., Chan, A.P.C. and Yam, M.C.H. (2013), "Determining Safety Climate Factors in 
the Repair, Maintenance, Minor Alteration, and Addition Sector of Hong Kong.” Journal of Construction Engineering and Management, 10.1061/(ASCE)CO.1943-7862.0000588, pp. 519-528.

Jarkas, A. and Bitar, C. (2012), Factors Affecting Construction Labor Productivity in Kuwait. Journal of Construction Engineering and Management, 10.1061/(ASCE)CO.19437862.0000501, pp. 811-820.

Jeong, S.-H. (2009), "Public's Responses to an oil spill accident: A test of the attribution theory and situational crisis communication theory." Public Relations Review, Vol. 35 No. 3, pp. $307-309$.

Kaliba, C., Muya, M., and Mumba, K. (2009), “Cost escalation and schedule delays in road construction projects in Zambia." International Journal of Project Management, Vol. 27 No. 5, pp. 522-531.

Kelley, H. H. and Michela, J. L. (1980), “Attribution theory and research.” Annual review of psychology, Vol. 31 No. 1, pp. 457-501.

Kwofie, T.E. (2015), Contribution of unique features of mass housing projects to project team communication performance. Unpublished $\mathrm{PhD}$ thesis. Kwame Nkrumah University of Science and Technology.

Kwofie, T. E., Adinyira, E. and Fugar, F. D. K. (2015), “An empirical assessment of ineffective communication inherent in the attributes of mass housing projects." Journal of Construction Project Management and Innovation, Vol. 5 No. 2, pp. 1176-1195.

Laczniak, R.N., DeCarlo, T.E. and Ramaswami, S.N. (2001), “Consumers' Responses to Negative Word-of-Mouth Communication: An Attribution Theory Perspective.” Journal of 
consumer Psychology, Vol. 11 No. 1, pp. 57-73.

Lalljee, M. (1987), Attribution theories and intercultural communication. In K. Knapp, W. Enninger, and A. Knapp-Potthof, eds. Analyzing intercultural communication. Mouton de Gruyter, New York, pp. 37-49.

Laryea, S. and Leiringer, R. (2012), Built environment research in West Africa: current trends and future directions In: Laryea, S., Agyepong, S.A., Leiringer, R. and Hughes, W. (Eds) Proc.s 4th West Africa Built Environment Research (WABER) Conference, 24-26 July 2012, Abuja, Nigeria, pp. 797-804.

Loosemore, M. and Lee, P. (2002), "Communication problems with ethnic minorities in the construction industry." International journal of project Management, Vol. 20 No. 7, pp. $517-524$.

Luo, L., Bippus, A. and Dunbar, N. E. (2005), "Causal attributions for collaborative public speaking presentations in college classes." Communication Reports, Vol. 18 No. 1-2, pp. $65-73$.

Meng, X. (2012), "The effect of relationship management on project performance in construction.” International Journal of Project Management, Vol. 30 No. 2, pp. 188-198.

Naoum, S.G. (2007), Dissertation research and writing for construction students, 2nd Ed., Butterworth-Heinemann, Oxford ; Burlington, MA.

Ng, S. T., Skitmore, R. M., Lam, K. C., and Poon, A. W. (2004), "Demotivating factors influencing the productivity of civil engineering projects." International Journal of Project Management, Vol. 22 No. 2, pp. 139-146. 
Ng, S.T., Eng Chen, S., McGeorge, D., Lam, K.C. and Evans, S. (2001), "Current state of IT usage by Australian subcontractors.” Construction Innovation, Vol. 1 No. 1, pp. 3-13.

O’Connor, B.P. (2000), “SPSS and SAS programs for determining the number of components using parallel analysis and Velicer's MAP test." Behavior research methods, instruments, and computers, Vol. 32 No. 3, pp. 396-402.

Ochieng, E.G. and Price, A.D.F. (2010), "Managing cross-cultural communication in multicultural construction project teams: The case of Kenya and UK." International journal of project Management, Vol. 28 No. 5, pp. 449-460.

Oyediran, O. S. and Akintola, A. A. (2011), "A survey of the state of the art of e-tendering in Nigeria." Journal of Information Technology in Construction, Vol. 16, pp. 557-576.

Peansupap, V., and Walker, D. (2005). "Factors affecting ICT diffusion: a case study of three large Australian construction contractors." Engineering, Construction and Architectural Management, Vol. 12 No. 1, pp. 21-37.

Peterson, D. K., Kim, C., Kim, J. H. and Tamura, T. (2002), “The perceptions of information systems designers from the United States, Japan, and Korea on success and failure factors." International Journal of Information Management, Vol. 22 No. 6, pp. 421-439.

Pietroforte, R. (1997), “Communication and governance in the building process." Construction Management and Economics, Vol. 15 No. 1, pp. 71-82.

Plotnik, R. and Kouyoumdjian, H. (2011), Introduction to psychology, 9th Ed., Wadsworth/Cengage Learning, Belmont, CA.

Ramanathan, C., Narayanan, S.P. and Idrus, A.B. (2012), “Construction delays causing risks on 
time and cost - a critical review." Australasian Journal of Construction Economics and Building, Vol. 12 No. 1, pp. 37-57.

Rogoff, E. G., Lee, M. S. and Suh, D. C. (2004), ““Who done it?” Attributions by entrepreneurs and experts of the factors that cause and impede small business success." Journal of Small Business Management, Vol. 42 No. 4, pp. 364-376.

Savolainen, R. (2013), “Approaching the motivators for information seeking: The viewpoint of attribution theories." Library and Information Science Research, Vol. 35 No. 1, pp. 63-68.

Shehu, Z. and Akintoye, A. (2010), "Major challenges to the successful implementation and practice of programme management in the construction environment: A critical analysis." International Journal of Project Management, Vol. 28 No. 1, pp. 26-39.

Shohet, I.M. and Frydman, S. (2003), "Communication patterns in construction at construction manager level." Journal of Construction Engineering and Management, 10.1061/(ASCE)0733-9364(2003)129:5(570), pp. 570-577.

Standing, C., Guilfoyle, A., Lin, C. and Love, P. E. (2006), "The attribution of success and failure in IT projects. Industrial Management and Data Systems, Vol. 106 No. 8, pp. 11481165.

Stein, T., Frankel, R.M. and Krupat, E. (2005), "Enhancing clinician communication skills in a large healthcare organization: A longitudinal case study." Patient education and counseling, Vol. 58 No. 1, pp. 4-12.

Stewart, A. E. (2005), "Attributions of responsibility for motor vehicle crashes." Accident Analysis and Prevention, Vol. 37 No. 4, pp. 681-688. 
Tai, S., Wang, Y. and Anumba, C.J. (2009). “A survey on communications in large-scale construction projects in China." Engineering, Construction and Architectural Management, Vol. 16 No. 2, pp. 136-149.

Thomas, S.R., Tucker, R.L. and Kelly, W.R. (1998), "Critical Communications Variables." Journal of Construction Engineering and Management, 10.1061/(ASCE)07339364(1998)124:1(58), pp. 58-66.

Tone, K., Skitmore, M. and Wong, J. K. W. (2009), "An investigation of the impact of crosscultural communication on the management of construction projects in Samoa." Construction Management and Economics, Vol. 27 No. 4, pp. 343-361.

Toor, S.-R. and Ogunlana, S.O. (2010). "Beyond the "iron triangle": Stakeholder perception of key performance indicators (KPIs) for large-scale public sector development projects." International Journal of Project Management, Vol. 28 No. 3, pp. 228-236.

Ulang, N.M., Gibb, A.G.F. and Anumba, C.J. (2009), "Communication of health and safety information in construction", in: Dainty, A. (Ed.) proceedings of the 25th Annual ARCOM Conference in Nottingham, UK, 2009, Association of Researchers in Construction Management, pp. 1233-41.

Weiner, B., 1980. Human Motivation, Holt, Rinehart and Winston, New York.

Weiner, B. (1985), “An attributional theory of achievement motivation and emotion." Psychological review, Vol. 92 No. 4, pp. 548-573

Wing, C.K., Raftery, J., and Walker, A. (1998). "The baby and the bathwater: Research methods in construction management." Construction Management and Economics, Vol. 16 No. 1, pp. 99-104. 
Xie, C., Wu, D., Luo, J. and Hu, X. (2010), “A case study of multi-team communications in construction design under supply chain partnering." Supply Chain Management: An International Journal, Vol. 15 No. 5, pp. 363-370.

Yin, R.K., 1994. Case study research : design and methods 2nd Ed., Sage Publications. 
Reply to the editor's and reviewers' comments

\begin{tabular}{|c|c|}
\hline Comment & Detailed description of response \\
\hline \multicolumn{2}{|l|}{ Editorial Comments } \\
\hline $\begin{array}{l}\text { I agree with this suggestion and would like to ask you } \\
\text { to re-structuring the paper along the comments of this } \\
\text { reviewer. }\end{array}$ & $\begin{array}{l}\text { We have revised and restructured the body of the manuscript in line with the } \\
\text { comments offered by the reviewer }\end{array}$ \\
\hline 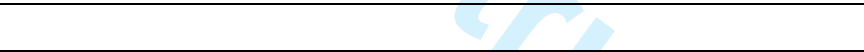 & \\
\hline Reviewer One & \\
\hline $\begin{array}{l}\text { 1). Please describe the process of statistical analysis } \\
\text { in the research method section. Maybe a process } \\
\text { schema would be good that shows the steps } \\
\text { conducted. Provide a narrative why the different } \\
\text { steps were done: ranking, factor analysis. As } \\
\text { mentioned all this in the research method and not in } \\
\text { the results/discussion section. }\end{array}$ & $\begin{array}{l}\text { We have revised and restructured the body of the manuscript. We have added a new } \\
\text { section titled "Tools for data analysis" (see Page } 10 \text { Line } 6 \text { - Page } 11 \text { Line } 6 \text { ). This } \\
\text { section explicitly explains the steps involved in mean score and factor analysis. }\end{array}$ \\
\hline $\begin{array}{l}\text { 2). Along the same lines it would be good to clearly } \\
\text { disentangle results (i.e. direct outcomes of the data } \\
\text { analysis) and discussion (i.e. interpretation of the } \\
\text { results in line with the previous literature) in two } \\
\text { different sections. At the moment, the text is jumping } \\
\text { between analysis and discussion a number of times } \\
\text { which makes it hard to understand the final } \\
\text { contributions well. }\end{array}$ & $\begin{array}{l}\text { We understand what the referee is saying. Based on this concern, we added a new } \\
\text { subsection titled "Discussion of mean score results" to the body of the manuscript (see } \\
\text { Page } 13 \text { Line } 8 \text { ). Also, the results (data analysis) and discussion section has also been } \\
\text { separated into two distinct sections. }\end{array}$ \\
\hline General comment & $\begin{array}{l}\text { The authors wish to thank the editors and reviewers for their time and effort in } \\
\text { reviewing our manuscript. We hope the changes listed have addressed the concerns. } \\
\text { Hence, the manuscript will be considered suitable for publication and we look forward } \\
\text { to your response. }\end{array}$ \\
\hline
\end{tabular}


